\title{
MAPPING KNOWLEDGE DOMAIN OF “TRANSPORT”: A BIBLIOMETRIC STUDY OF ITS STATUS QUO AND EMERGING TRENDS
}

\author{
Wei ZHOU ${ }^{1}$, Zeshui XU²*, Paulius SKAČKAUSKAS ${ }^{3 *}$ \\ ${ }^{1}$ School of Finance, Yunnan University of Finance and Economics, Kunming, China \\ ${ }^{2}$ Business School, State Key Laboratory of Hydraulics and Mountain River Engineering, Sichuan University, \\ Chengdu, China \\ ${ }^{3}$ Laboratory of Transport Engineering and Logistics, Vilnius Gediminas Technical University, Vilnius, Lithuania
}

Received 4 November 2019; revised 9 December 2019; accepted date 14 December 2019

\begin{abstract}
Transport plays an important role in human society. Due to its significance, the research journal TRANSPORT was established with the aim of developing and reinforcing the performance of national transport system based on theoretical and empirical investigations. The analyses such as transport policy, transport system fundamentals, multiple transport methods and traffic safety are all within the research scope of TRANSPORT. Therefore, this paper focuses on learning the development of this multidisciplinary journal by using the bibliometric tools. After analysing 704 papers published from January 2007 to June 2019 on TRANSPORT, the development of this journal is comprehensively analysed from the perspectives of its status quo and emerging trends. Specifically, the current status is introduced based on the general journal information, the publication and citation number, the citation structure and the significant contributors in terms of author, journal, institution and country. As for the emerging trends, the citation burst detections and the timeline view analysis are presented to give some deep insights of the hot research streams in certain time periods. This paper makes the contribution to provide a knowledge map of the journal TRANSPORT's research domain to help researchers learn this journal and transport-related issues clearly and directly. It can be also considered as the reference source for further investigations.
\end{abstract}

Keywords: transport, publishing, bibliometric, knowledge map, emerging trend.

\section{Introduction}

According to the explanation of "transport" in "The Cambridge Dictionary of Philosophy" (Audi 2015), it is defined as the movement of human beings, goods or cattle from one place to another. Look back on history, each evolution of transport leads to tremendous change in human society and civilization. From the Silk Road to the European Age of Exploration, from the invention of the steam engine to the launch of Apollo program, what we have eliminated is not merely geographic distances, but the gap between known and unknown. Therefore, transport plays a significant role for world development from different perspectives, making it more prevailing to research on transport-related issues. As one of the journals in this research area, TRANSPORT published its first issue (under the new title) in 2002. Later on, this journal releases many research outputs in different directions such as transport policy, transport system and traffic safety with the aim of developing and improving the national transport system through theoretical and empirical investigations. As a result, we are motivated to conduct a bibliometric study of the research published on TRANSPORT with regard to its status quo and emerging trends. This study makes contributions to provide access to a better understanding of transport-related issues. In addition, it helps researchers know more about the growth and aims of this journal.

To achieve the above aim, this paper is organized as follows: Section 1 introduces the basic information of TRANSPORT, then publications, citation numbers and citation structure of this journal are analysed in Section 2. Further, Section 3 gives some details about the significant contributors in terms of the influential papers, countries, institutions, and authors. The above sections comprehensively analyse the status quo of TRANSPORT. The emerging trends and hot spots of the research published on this journal are presented in Section 4. The conclusion is given in the last section.

*Corresponding author. E-mail: xuzeshui@263.net

\#Managing Editor of the TRANSPORT - the manuscript was handled by one of the Editors, who made all decisions related to the manuscript (including the choice of referees and the ultimate decision on the revision and publishing).

Copyright @ 2019 The Author(s). Published by VGTU Press

This is an Open Access article distributed under the terms of the Creative Commons Attribution License (http://creativecommons.org/licenses/by/4.0/), which permits unrestricted use, distribution, and reproduction in any medium, provided the original author and source are credited. 


\section{Basic information about TRANSPORT}

In order to describe the current status of TRANSPORT, a general picture about its scopes and editor information is given. From the website of TRANSPORT, we can find that this journal is an international peer-reviewed journal including the main aspects of transport. It also provides a source of information for the engineer and the applied scientist. The detailed focuses of the publications can be found in Table 1. From this table, it can be seen that this journal focuses on many issues related to transport, such as transport policy, transport system, transport tools, transport economics and management, transport educology and history, etc. Obviously, these issues include all the hot and useful directions in the transport field.

We can also find that the first issue of this journal was published (under the new title) in 2002. From 2002 to 2005 , this journal published papers bimonthly, namely 6 volumes every year. Then, this journal published papers quarterly from 2006 to 2017 , namely 4 volumes every year. In 2018, it published 5 volumes. Until June 2019, 81 volumes were released. Moreover, this journal was indexed in Clarivate Analytics Web of Science in 2007. Now, TRANSPORT is indexed in many famous databases such as Science Citation Index Expanded (SCI-Expanded), Ei Compendex, and Scopus. In the SCI-Expanded database, this journal ranks 22/25 in the Transportation Science \& Technology filed and belongs to a Q3 journal. In the Scopus database, this journal is classified as the Q2 journal. Note that this study focuses on the papers published in TRANSPORT and indexed in Clarivate Analytics Web of Science, and the analysed publications were published from January 2007 to June 2019.

Table1. The focuses of the TRANSPORT publications

\begin{tabular}{|c|l|}
\hline Rank & \multicolumn{1}{|c|}{ Focuses } \\
\hline 1 & transport policy \\
\hline 2 & fundamentals of the transport system \\
\hline 3 & $\begin{array}{l}\text { technology for carrying passengers and freight using } \\
\text { road, railway, inland waterways, sea and air transport }\end{array}$ \\
\hline 4 & $\begin{array}{l}\text { technology for multimodal transportation and } \\
\text { logistics }\end{array}$ \\
\hline 5 & loading technology \\
\hline 6 & roads, railways \\
\hline 7 & airports, ports \\
\hline 8 & traffic safety and environment protection \\
\hline 9 & $\begin{array}{l}\text { design, manufacture and exploitation of motor } \\
\text { vehicles }\end{array}$ \\
\hline 10 & transport energetics \\
\hline 11 & fuels, lubricants and maintenance materials \\
\hline 12 & teamwork of customs and transport \\
\hline 13 & transport information technologies \\
\hline 14 & $\begin{array}{l}\text { transport economics and management; transport } \\
\text { standards }\end{array}$ \\
\hline 15 & transport educology and history \\
\hline
\end{tabular}

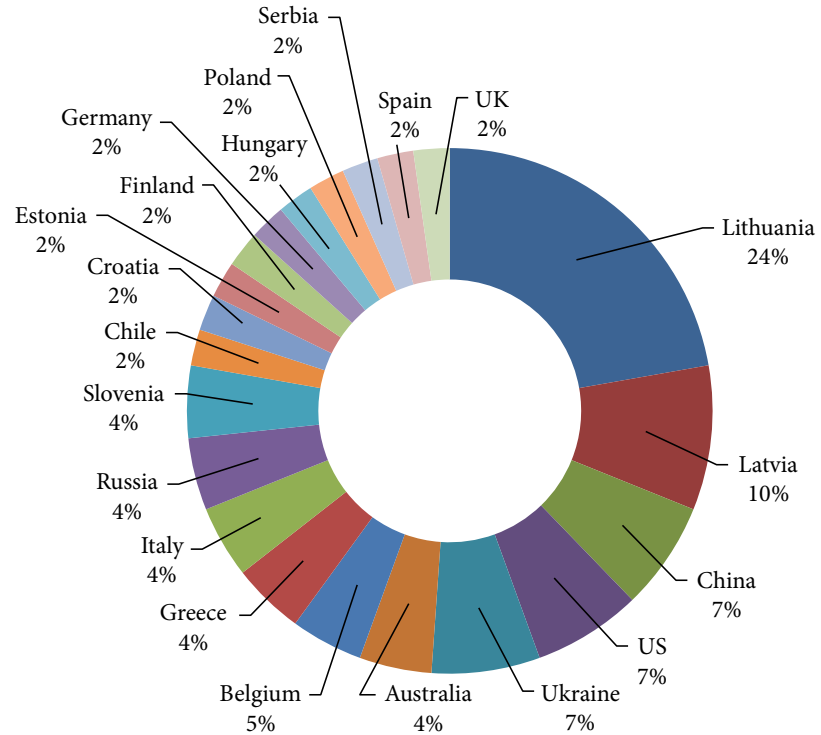

Figure 1. The national distribution of all the editors

In Table 2, we present the editor list of TRANSPORT. According to this table, we can find that Prof. Olegas Prentkovskis from Vilnius Gediminas Technical University has been elected Editor-in-Chief of the journal. Assoc. Prof. Raimundas Junevičius and MSc. Paulius Skačkauskas are respectively Deputy Editor-in-Chief and Managing Editor of this journal.

Figure 1 further presents the geographical distribution of the editors of this journal. From Table 2 and Figure 1, we can find that the editors come from different countries and institutions, showing that this is an international academic journal.

\section{Research methodology}

The betweenness centrality is a significant parameter for bibliometric tools such as CiteSpace and VOSviewer to investigate vital co-citing networks (Yu et al. 2019b). According to Chen (2004) and Yu et al. (2019c), the centrality can be considered as a node that quantifies the importance of its position in a network. Therefore, the centrality is calculated and defined as follows:

$$
\text { Centrality }\left(\text { node }_{i}\right)=\sum_{i \neq j \neq k} \frac{\delta_{i k}(i)}{\delta_{j k}},
$$

where: $\delta_{j k}$ represents the number of short paths between the nodes $j$ and $k$; $\delta_{i k}(i)$ means the number of the short paths that cross the node $i$.

According to the betweenness centrality, this paper that makes significant contributions in specific areas or journals can be found. In addition, comprehensive investigations provided by the timeline and the burst detection are also identified based on betweenness centrality. Moreover, some key terms and indexes should be adjusted to present the analytic results more clearly and directly. For example, in terms of time slice, we select 1 year per 
Table 2. The editor list of TRANSPORT

\begin{tabular}{|c|c|c|c|}
\hline & Name & Country & Institution \\
\hline Editor-in-Chief & Olegas Prentkovskis & Lithuania & Vilnius Gediminas Technical University \\
\hline Deputy Editor-in-Chief & Raimundas Junevičius & Lithuania & Vilnius Gediminas Technical University \\
\hline Managing Editor & Paulius Skačkauskas & Lithuania & Vilnius Gediminas Technical University \\
\hline \multirow{6}{*}{ Associate Editors } & Ying-En Ge & China & Shanghai Maritime University \\
\hline & Kasthurirangan Gopalakrishnan & US & Iowa State University \\
\hline & Georges Kouroussis & Belgium & University of Mons \\
\hline & Vidas Žuraulis & Lithuania & Vilnius Gediminas Technical University \\
\hline & Raimundas Junevičius & Lithuania & Vilnius Gediminas Technical University \\
\hline & Paulius Skačkauskas & Lithuania & Vilnius Gediminas Technical University \\
\hline \multirow{36}{*}{ Editors } & Andrus Aavik & Estonia & Tallinn University of Technology \\
\hline & Andrii Bieliatynskyi & Ukraine & National Aviation University \\
\hline & John D. Bullough & US & Lighting Research Center, Rensselaer Polytechnic Institute \\
\hline & Gintautas Bureika & Lithuania & Vilnius Gediminas Technical University \\
\hline & Ivan Dyakov & Russia & Ulyanovsk State Technical University \\
\hline & $\begin{array}{l}\text { George Anastasios } \\
\text { Giannopoulos }\end{array}$ & Greece & $\begin{array}{l}\text { Hellenic Institute of Transport, Center for Research and } \\
\text { Technology Hellas }\end{array}$ \\
\hline & Sarfaraz Hashemkhani Zolfani & Chile & Catholic University of the North \\
\hline & Mirano Hess & Croatia & University of Rijeka \\
\hline & Valentin Ivanov & Germany & Ilmenau University of Technology \\
\hline & Jolanta Janutėnienè & Lithuania & Klaipèda University \\
\hline & Jadranka Jović & Serbia & University of Belgrade \\
\hline & Igor Kabashkin & Latvia & Transport and Telecommunication Institute \\
\hline & Uroš Klanšek & Slovenia & University of Maribor \\
\hline & Iryna Klymenko & Ukraine & National University of Transport \\
\hline & Pavlo Maruschak & Ukraine & Ternopil Ivan Pul'uj National Technical University \\
\hline & Gabriella Mazzulla & Italy & University of Calabria \\
\hline & Enrique Onieva & Spain & University of Deusto \\
\hline & Sergey Panin & Russia & $\begin{array}{l}\text { Institute of Strength Physics and Materials Science, Siberian } \\
\text { Branch of Russian Academy of Sciences }\end{array}$ \\
\hline & Orazio Pellegrino & Italy & University of Messina \\
\hline & Carlo Giacomo Prato & Australia & University of Queensland \\
\hline & Laurencas Raslavičius & Lithuania & Kaunas University of Technology \\
\hline & Josep Maria Salanova Grau & Greece & $\begin{array}{l}\text { Hellenic Institute of Transport, Center for Research and } \\
\text { Technology Hellas }\end{array}$ \\
\hline & Wafaa Saleh & UK & Edinburgh Napier University \\
\hline & Marek Sitarz & Poland & University of Dąbrowa Górnicza \\
\hline & Juris Smirnovs & Latvia & Riga Technical University \\
\hline & Edgar Sokolovskij & Lithuania & Vilnius Gediminas Technical University \\
\hline & Maksym Spiryagin & Australia & Central Queensland University \\
\hline & Ulla Pirita Tapaninen & Finland & University of Turku \\
\hline & Ádám Török & Hungary & Budapest University of Technology and Economics \\
\hline & Elen Twrdy & Slovenia & University of Ljubljana \\
\hline & Jānis Vība & Latvia & Riga Technical University \\
\hline & Yonggang Wang & China & Chang'an University \\
\hline & Dali Wei & US & $\begin{array}{l}\text { Institute of Transportation Studies, University of California } \\
\text { Berkeley }\end{array}$ \\
\hline & Frank Witlox & Belgium & Ghent University \\
\hline & Irina Yatskiv (Jackiva) & Latvia & Transport and Telecommunication Institute \\
\hline & Shengyang Zhu & China & Southwest Jiaotong University \\
\hline
\end{tabular}


slice from January 2007 to June 2019. The appropriate thresholds are adjusted in the modelling and visualizing procedure to make the major results clear to see.

\section{The publications, citation numbers and citation structure of TRANSPORT}

In this section, the status quo and the development of TRANSPORT are analysed based on the annual publications and the citation number of this journal. It is believed that the publication and citation numbers can directly reflect the general development trend of TRANSPORT. In addition, the citation structure is presented to see the impact made by this journal in each year.

\subsection{Data collection and analysis}

We utilize two influential bibliometric analysis tools in this paper, namely CiteSpace and VOSviewer to present the network mapping and visualize the knowledge domain of TRANSPORT. Here, CiteSpace is a knowledge domain visualization software developed by Chen (2004). It is broadly utilized in different research areas such as computer science (Morar, Agachi 2010; Niazi, Hussain 2011; Yu et al. 2019a, 2019d), medicine (Chen et al. 2012), psychology (Zhang et al. 2015), economy (Cui, Zhang 2018), and management (Ekanayake et al. 2019). Similarly, VOSviewer is a broadly used bibliometric tool, which was developed by Van Eck and Waltman (2007) to construct and view bibliometric maps. There are also many bibliometric investigations using VOSviewer from the perspectives of social science (Heersmink et al. 2011), computer science (Kozak et al. 2015; Stopar, Bartol 2019), neurosciences (Yeung et al. 2017), environmental health (Sweileh 2017), bioscience (Zhao et al. 2018), and sustainable logistics (Qaiser et al. 2017). It can be found that these two bibliometric analysis tools are different and can achieve different functions respectively. Therefore, both of these two tools are used in this paper.

In addition, Clarivate Analytics Web of Science is chosen as the data source, which includes the significant databases such as SCI-Expanded, Social Sciences Citation Index (SSCI), Arts \& Humanities Citation Index (A\&HCI), Emerging Sources Citation Index (ESCI). By searching the journal name "TRANSPORT", the amount of 704 publications on TRANSPORT are found. These papers have been published from January 2007 to June 2019. There are two reasons for this paper to select this research period:

1) this journal was indexed by Clarivate Analytics Web of Science in 2007;

2) the most up-dated data on Clarivate Analytics Web of Science are available in June 2019.

Figures $2 \mathrm{a}$ and $2 \mathrm{~b}$ respectively list the annual distributions of the TRANSPORT citations and publications from January 2007 to June 2019. Due to the fact that even though TRANSPORT published the first issue in 2002, it was collected by Clarivate Analytics Web of Science un- til 2007. As can be seen from Figure 2, the number of the publications from 2007 to 2017 is relatively stable. It should be pointed out that the research outputs in 2018 reached the peak with 113 papers, which is about twice as many as those previous years. The publications in 2018 focus more on public transport and sea transport.

Moreover, Figure 3 shows the types of the TRANSPORT publications. From Figure 3, we can further find that all the publications in TRANSPORT are divided into 5 types according to the results given by Clarivate Analytics Web of Science. Articles occupy a large proportion of the whole publications with 670 papers, while 15 papers belong to the type of reviews and 10 papers are editorial materials. Moreover, 7 papers are classified as corrections. Additionally, there are only 2 papers about biographical items.

a)

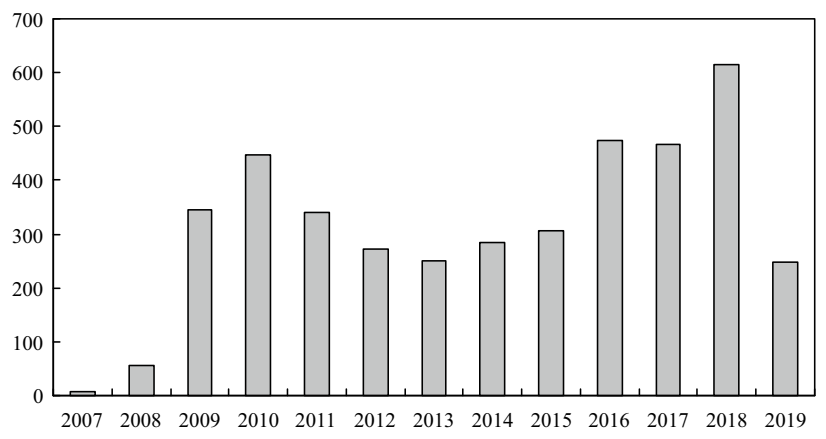

b)

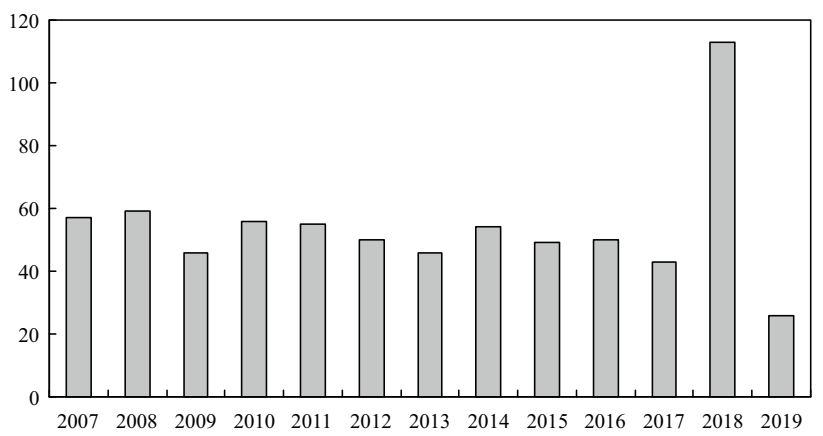

Figure 2. Distribution of the TRANSPORT publications and citations from January 2007 to June 2019: a - the citation number; $b$ - the publication number
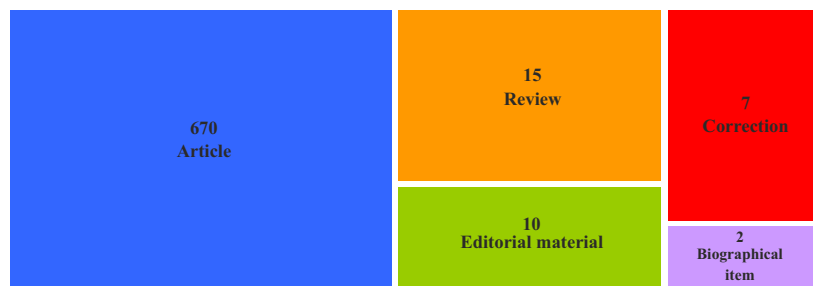

Figure 3. Types of the TRANSPORT publications from January 2007 to June 2019 


\subsection{Citation structure analysis of TRANSPORT}

A key index to make an appraisal of the impact of an academic journal is its citation number. Thus, the impact factor of a journal is calculated and released annually to show its significance in specific research area. Therefore, in this subsection, we further analyse TRANSPORT on the aspect of citation structure.

First, we find that the citation number of TRANSPORT has two rising periods from 2007 to 2010 and from 2013 to 2018 , respectively. In addition, the citation number of TRANSPORT in 2018 rose at the maximal point. Note that the publication and citation numbers of TRANSPORT in 2019 are incomplete. As a result, it means that the more people paid more attention to the research published in this journal in recent years and the previous papers in TRANSPORT have great impact on the study for current research area.

Second, Table 3 is given to demonstrate the annual publication characteristics of TRANSPORT, which could clearly present the detailed information of the TRANSPORT publications. In Table 3, "TP", "TC" and "AC" respectively mean the Total Publications, the Total Citations, and the Average Citations per paper in each year until 2019. Besides, " $\geq 100$ ", " $\geq 50$ ", " $\geq 20$ ", " $\geq 10$ " and " $\geq 5$ " represent different intervals of the citation numbers. These interval numbers are used to count the number of papers that reach the corresponding citations from January 2007 to June 2019.

Moreover, $h$-index is a useful parameter that can accurately evaluate the literature in terms of academic achievement. If the value is high, the achievement will be great (Díaz et al. 2016). From Table 3, it can be seen that as time goes by, the $h$-index roughly become lower. Similarly, AC roughly declines with the year. The publications in 2008 have the most TC, AC and $h$-index. In addition, according to the data from Clarivate Analytics Web of Science, there is 1 paper published in 2008 and it reaches the standard of " $\geq 100$ ", which means that the paper has been cited more than 100 times. Hence, the publications in 2008 contribute a lot to TRANSPORT. Moreover, the publications in 2008,2010 , and 2011 achieve the standard of " $\geq 50$ ", we will concretely introduce and analyse these papers in the following section.

\section{Influential papers, countries, institutions, and authors of TRANSPORT}

To further comprehensively show more information about TRANSPORT, the most influential papers, countries, institutions and authors are analysed in the following content.

Table 4 is provided to show the top 20 most cited papers in TRANSPORT from January 2007 to June 2019. We find that all the 20 papers were published before 2014. In particular, the paper "Multi-objective decision-making for road design" (Brauers et al. 2008) has the most TC with 108 , which is far more than other listed papers. This paper focuses on developing and implementing a kind of way for multi-objective optimization of multi-alternative decisions in road construction and determines the best road design. The paper "A new fuzzy additive ratio assessment method (ARAS-F). Case study: the analysis of fuzzy multiple criteria in order to select the logistic centers location" (Turskis, Zavadskas 2010) is ranked at the second indicating the paper that makes significant impact on this field and the following authors. Turskis and Zavadskas (2010) introduced a new method to help people choose the best site, which also could be suitable for the field of construction, economics, technology and sustainable development.

Moreover, in Table 4, the author Sivilevičius is listed frequently. His most cited paper is "Modelling the interaction of transport system elements", which analyses

Table 3. TRANSPORT publication characteristics from 2007 to June 2019

\begin{tabular}{|c|c|c|c|c|c|c|c|c|c|}
\hline Year & TP & TC & AC & $h$-index & $\geq 100$ & $\geq 50$ & $\geq 20$ & $\geq 10$ & $\geq 5$ \\
\hline 2007 & 57 & 597 & 10.47 & 14 & 0 & 0 & 7 & 23 & 42 \\
\hline 2008 & 59 & 763 & 12.93 & 15 & 1 & 3 & 8 & 27 & 43 \\
\hline 2009 & 46 & 475 & 10.33 & 13 & 0 & 0 & 6 & 18 & 34 \\
\hline 2010 & 56 & 514 & 9.18 & 11 & 0 & 2 & 4 & 15 & 38 \\
\hline 2011 & 55 & 369 & 6.71 & 10 & 0 & 2 & 3 & 12 & 27 \\
\hline 2012 & 50 & 260 & 5.2 & 9 & 0 & 0 & 0 & 7 & 26 \\
\hline 2013 & 46 & 241 & 5.24 & 8 & 0 & 0 & 2 & 7 & 14 \\
\hline 2014 & 54 & 271 & 5.02 & 8 & 0 & 0 & 2 & 7 & 19 \\
\hline 2015 & 49 & 221 & 4.51 & 8 & 0 & 0 & 0 & 6 & 22 \\
\hline 2016 & 50 & 177 & 3.54 & 6 & 0 & 0 & 1 & 2 & 13 \\
\hline 2017 & 43 & 133 & 3.09 & 6 & 0 & 0 & 0 & 4 & 10 \\
\hline 2018 & 113 & 97 & 0.86 & 4 & 0 & 0 & 0 & 0 & 3 \\
\hline 2019 & 26 & 5 & 0.19 & 1 & 0 & 0 & 0 & 0 & 0 \\
\hline Total & 704 & 4123 & - & - & 1 & 7 & 33 & 128 & 291 \\
\hline Percentage & - & - & - & - & $0.14 \%$ & $0.99 \%$ & $4.69 \%$ & $18.18 \%$ & $41.34 \%$ \\
\hline
\end{tabular}

Notes: TP - total publications; TC - total citations; AC - average citations; $h$-index - Hirsch index. 
the interaction of separate TS elements, it is concluded that there is no common model could be used to all types of interaction (Sivilevičius 2011). The 20 papers are all of great benefit to TRANSPORT.
Table 5 is provided to demonstrate the top 10 most influential countries of the TRANSPORT publications. As the country that subsidizes and publishes this journal, Lithuania is obviously the most influential country.

Table 4. Top 20 most cited papers in TRANSPORT from January 2007 to June 2019

\begin{tabular}{|c|c|c|c|c|c|}
\hline Rank & Title & Author(s) & Year & TC & $\mathrm{AC}$ \\
\hline 1 & Multi-objective decision-making for road design & Brauers et al. & 2008 & 108 & 9.0 \\
\hline 2 & $\begin{array}{l}\text { A new fuzzy additive ratio assessment method (ARAS-F). Case study: the analysis } \\
\text { of fuzzy multiple criteria in order to select the logistic centers location }\end{array}$ & Turskis et al. & 2010 & 77 & 7.7 \\
\hline 3 & The effect of iso-butanol-diesel blends on engine performance & Al-Hasan et al. & 2008 & 64 & 5.3 \\
\hline 4 & Multiple-criteria decision support system in highway infrastructure management & Šelih et al. & 2008 & 58 & 4.8 \\
\hline 5 & Modelling the interaction of transport system elements & Sivilevičius & 2011 & 54 & 6.0 \\
\hline 6 & $\begin{array}{l}\text { The criteria for identifying the quality of passengers' transportation by railway and } \\
\text { their ranking using AHP method }\end{array}$ & $\begin{array}{l}\text { Sivilevičius, } \\
\text { Maskeliūnaitè }\end{array}$ & 2010 & 51 & 5.1 \\
\hline 7 & $\begin{array}{l}\text { Multiple criteria decision-making techniques in transportation systems: a } \\
\text { systematic review of the state of the art literature }\end{array}$ & Mardani et al. & 2016 & 47 & 11.8 \\
\hline 8 & Research on dry port concept as intermodal node & $\begin{array}{l}\text { Jaržemskis, } \\
\text { Vasilis Vasiliauskas }\end{array}$ & 2007 & 47 & 3.6 \\
\hline 9 & Research on the quality of passenger transportation by railway & Maskeliūnaitè et al. & 2009 & 40 & 3.6 \\
\hline 10 & $\begin{array}{l}\text { Automobile transport system analysis and ranking in Lithuanian administrative } \\
\text { regions }\end{array}$ & $\begin{array}{l}\text { Jakimavičius, } \\
\text { Burinskienė }\end{array}$ & 2007 & 40 & 3.1 \\
\hline 11 & $\begin{array}{l}\text { Developing a new hybrid MCDM method for selection of the optimal alternative } \\
\text { of mechanical longitudinal ventilation of tunnel pollutants during automobile } \\
\text { accidents }\end{array}$ & $\begin{array}{l}\text { Hashemkhani } \\
\text { Zolfani et al. }\end{array}$ & 2013 & 33 & 4.71 \\
\hline 12 & $\begin{array}{l}\text { The use of AHP and rank correlation methods for determining the significance } \\
\text { of the interaction between the elements of a transport system having a strong } \\
\text { influence on traffic safety }\end{array}$ & $\begin{array}{l}\text { Podvezko, } \\
\text { Sivilevičius }\end{array}$ & 2013 & 33 & 4.7 \\
\hline 13 & $\begin{array}{l}\text { Improvement of road safety using passive and active intelligent vehicle safety } \\
\text { systems }\end{array}$ & $\begin{array}{l}\text { Jarašūnienè, } \\
\text { Jakubauskas }\end{array}$ & 2007 & 31 & 2.4 \\
\hline 14 & Logistics freight center locations decision by using Fuzzy-PROMETHEE & Elevli & 2014 & 28 & 4.7 \\
\hline 15 & $\begin{array}{l}\text { Key factors affecting rail service quality in the northern Italy: a decision tree } \\
\text { approach }\end{array}$ & De Oña et al. & 2014 & 28 & 4.7 \\
\hline 16 & The impact of transport on the competitiveness of national economy & Mačiulis et al. & 2009 & 28 & 2.6 \\
\hline 17 & $\begin{array}{l}\text { The calculation and measurement of the natural frequencies of the bucket wheel } \\
\text { excavator SchRs } 1320 / 4 \times 30\end{array}$ & Gottvald & 2010 & 27 & 2.7 \\
\hline 18 & $\begin{array}{l}\text { Principle and benefits of third party logistics approach when managing logistics } \\
\text { supply chain }\end{array}$ & $\begin{array}{l}\text { Vasilis Vasiliauskas, } \\
\text { Jakubauskas }\end{array}$ & 2007 & 27 & 2.1 \\
\hline 19 & $\begin{array}{l}\text { Measuring efficiency in transport: the state of the art of applying data envelopment } \\
\text { analysis }\end{array}$ & Markovits-Somogyi & 2011 & 26 & 2.9 \\
\hline 20 & Investigating traffic accidents: a collision of two motor vehicles & Prentkovskis et al. & 2010 & 26 & 2.6 \\
\hline
\end{tabular}

Table 5. Top 10 most influential countries of the TRANSPORT publications

\begin{tabular}{|c|l|l|c|c|c|c|c|c|c|c|c|}
\hline Rank & \multicolumn{1}{|c|}{ Country } & \multicolumn{1}{|c|}{ Continent } & TP & TC & AC & $h$-index & $\geq 100$ & $\geq 50$ & $\geq 20$ & $\geq 10$ & $\geq 5$ \\
\hline 1 & Lithuania & Europe & 242 & 2041 & 8.43 & 20 & 1 & 4 & 20 & 68 & 129 \\
\hline 2 & China & Asia & 104 & 345 & 3.32 & 9 & 0 & 0 & 0 & 7 & 24 \\
\hline 3 & USA & North America & 39 & 125 & 3.21 & 6 & 0 & 0 & 0 & 4 & 10 \\
\hline 4 & Serbia & Europe & 36 & 117 & 3.25 & 5 & 0 & 0 & 1 & 3 & 8 \\
\hline 5 & Hungary & Europe & 34 & 239 & 7.03 & 10 & 0 & 0 & 3 & 10 & 18 \\
\hline 6 & Poland & Europe & 31 & 139 & 4.48 & 8 & 0 & 0 & 0 & 6 & 12 \\
\hline 7 & Turkey & Asia & 27 & 183 & 6.78 & 8 & 0 & 0 & 2 & 6 & 15 \\
\hline 8 & Iran & Asia & 26 & 181 & 6.96 & 8 & 0 & 0 & 2 & 7 & 12 \\
\hline 9 & Italy & Europe & 25 & 136 & 5.44 & 7 & 0 & 0 & 1 & 2 & 13 \\
\hline 10 & Ukraine & Europe & 24 & 130 & 5.42 & 7 & 0 & 0 & 0 & 4 & 10 \\
\hline
\end{tabular}


The TP, TC, AC and $h$-index of the publications in Lithuania are all above those in other countries. Even more, there are 4 papers of Lithuania have been cited above the standard level of " $\geq 50$ ". In addition, among the 10 countries, there are 6 countries come from Europe that occupies the most proportion, the following is Asia. Notably, although Hungary is in the fifth place, the AC and $h$-index are second only to Lithuania. It is found that Hungary concentrates on the research in the scope of TRANSPORT and makes significant contributions to the growth and aims of this journal.

Figure 4 is given to show the country co-authorship network of the TRANSPORT publications. As we know, the co-authorship analysis is one of the most useful and practical method to study the relationship of cooperation (Reyes-Gonzalez et al. 2016). As a result, we set the threshold value of the minimum number of documents at 5 , then 27 countries were selected. VOSviewer is used to present the country co-authorship network map. In the calculation process, the size of the node is determined by the publications' weights. More publications owned by a country leads larger label value of this country. Moreover, the line between each two countries denotes that they have connections, and the line's thickness reflects how close is the cooperation between these two countries. From Figure 4, we can find that Lithuania is the main contributor of TRANSPORT. It has 19 links and its total link strength is 52, which means that Lithuania has cooperated with other 19 countries, and 52 publications were written on the basis of the collaboration between Lithuania and the 19 countries. The following nation is China with 6 links and 20 total link strength. Nowadays, due to the development of international academic communication, there is an increasing number of collaborations among different countries to work on transport-related issues.

Table 6 lists the 10 most productive and influential institutions in TRANSPORT. It is obvious that the Vilnius Gediminas Technical University is the most influential institution in this journal. It has the highest TP, TC, AC and $h$-index values. It should be noted that although the publication number of Aleksandras Stulginskis University (currently Vytautas Magnus University) in this journal is relatively small with only 21 papers, the AC value of these papers is 7.62 , which means the 21 papers are all influential and crucial for further research. In addition, among the 10 institutions, $40 \%$ of the institutions are from Lithuanian. Therefore, the published studies from Lithuanian institutions greatly impact the research of TRANSPORT.

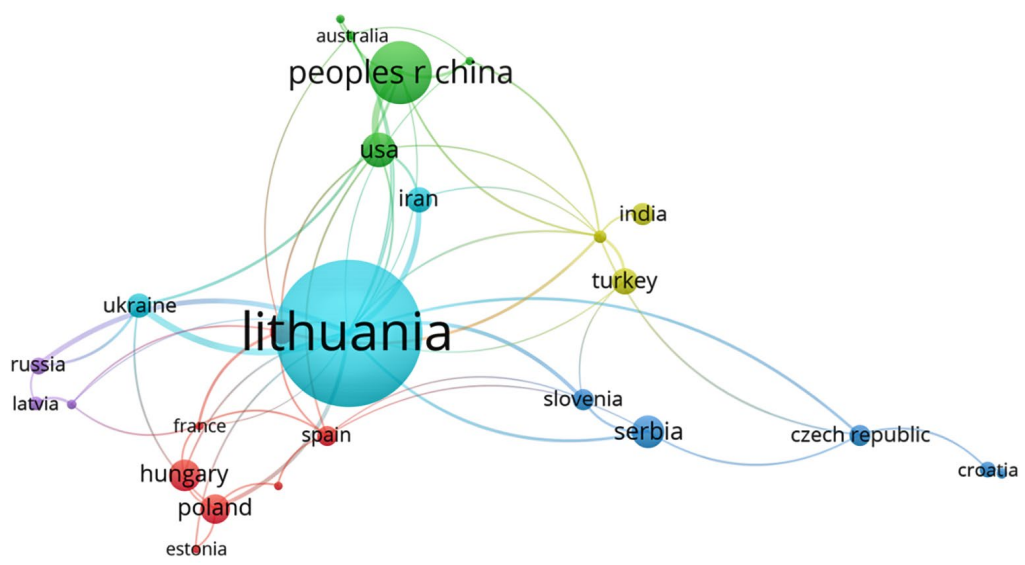

Figure 4. Country co-authorship network of the TRANSPORT publications

Table 6. The most productive and influential institutions in TRANSPORT

\begin{tabular}{|c|l|l|c|c|c|c|}
\hline Rank & \multicolumn{1}{|c|}{ Institution } & \multicolumn{1}{|c|}{ Country/territory } & TP & TC & AC & $h$-index \\
\hline 1 & Vilnius Gediminas Technical University & Lithuania & 173 & 1661 & 9.6 & 19 \\
\hline 2 & University of Belgrade & Serbia & 34 & 111 & 3.26 & 5 \\
\hline 3 & Budapest University of Technology and Economics & Hungary & 31 & 204 & 6.58 & 9 \\
\hline 4 & Klaipėda university & Lithuania & 29 & 120 & 4.14 & 6 \\
\hline 5 & Kaunas University of Technology & Lithuania & 28 & 176 & 6.29 & 9 \\
\hline 6 & $\begin{array}{l}\text { Aleksandras Stulginskis University (currently } \\
\text { Vytautas Magnus University) }\end{array}$ & Lithuania & 21 & 160 & 7.62 & 8 \\
\hline 7 & Southeast University & China & 19 & 56 & 2.95 & 4 \\
\hline 8 & Indian Institute of Technology System & India & 16 & 82 & 5.13 & 6 \\
\hline 9 & National Aviation University & Ukraine & 13 & 89 & 6.85 & 5.86 \\
\hline 10 & University of Pardubice & Czech Republic & 5 \\
\hline
\end{tabular}




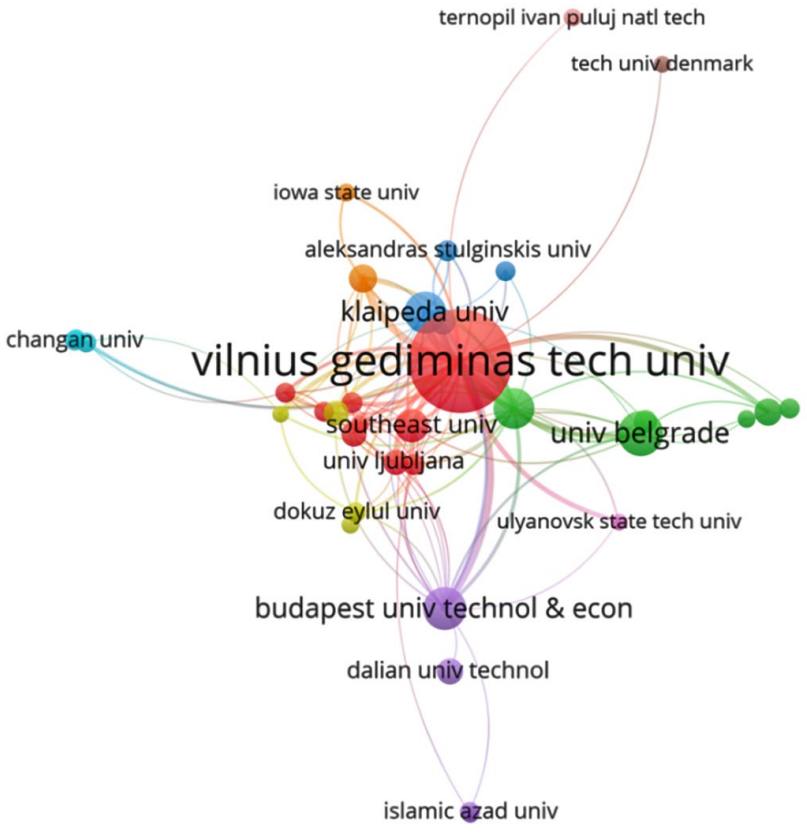

Figure 5. Organization citation network of the TRANSPORT publications

The organization citation network is summarized in Figure 5. Similarly, we set the threshold value of the minimum number of documents at 5 . Then, there are 36 organizations can be selected. Obviously, the Vilnius Gediminas Technical University is the predominant institution, and its link is 31 and total link strength is 342 , which means that the papers from the Vilnius Gediminas Technical University have been cited by other 31 institutions with the total citations of 342 .

Another important part of the author analysis is the cited authors' co-citation analysis, which is introduced by Small (1973). The cited authors' co-citation network is presented in Figure 6. Here, we set the threshold value at 20 , namely the authors who have been cited for over 20 times. Then, there are 36 authors who meet this threshold.

\section{Burst detection and keywords analysis of TRANSPORT}

Kleinberg (2002) pointed out that citation burst analysis is used to dig out the explosive data in the certain period of time. It can help us find out the hot topic in a specific research field. Therefore, in the following content, we use the citation burst analysis to show the burst detection of TRANSPORT. The results are shown in Table 7.

Table 7 lists the top 15 journals that are frequently cited by the papers published on TRANSPORT. It is noted that the last column of Table 7 shows the citation bursts intensity of the cited journals from 2007 to 2019. The red colour means that the intensity of citation bursts exceeds the set threshold. Therefore, the first cited journal with the strongest citation burst is Transport and Telecommunication, and the citation bursts began in 2007 and ended in

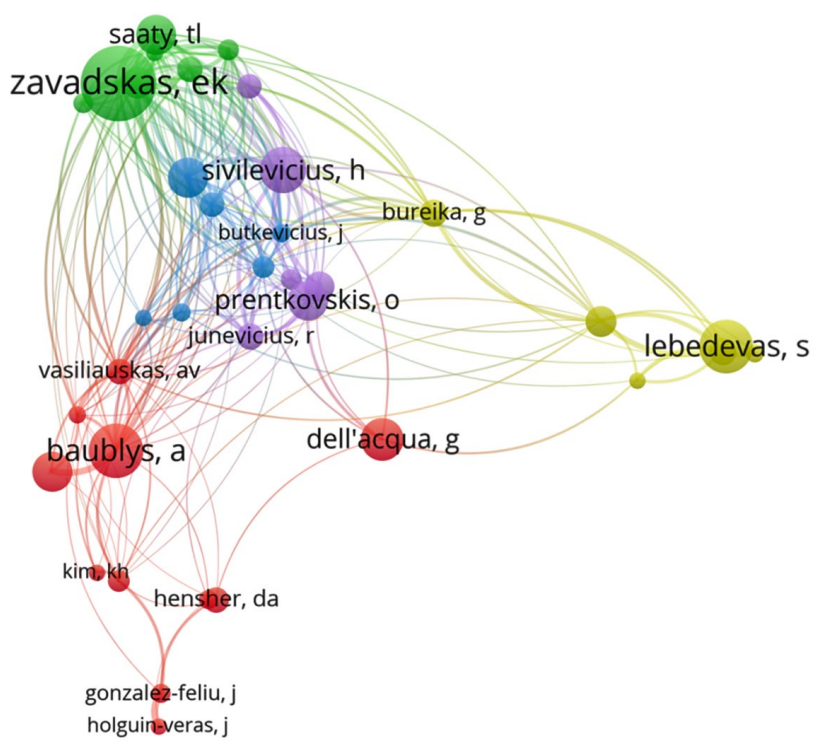

Figure 6. Cited authors' co-citation network of the TRANSPORT publications

2010. Journal of Civil Engineering and Management, Journal of Business Economics and Management and Baltic Journal of Road and Bridge Engineering have the longest duration for 4 years. Journal of Civil Engineering and Management involves the areas of civil engineering and management. Journal of Business Economics and Management focuses more on economics, finance, investment and marketing. Baltic Journal of Road and Bridge Engineering was established in 2006, and its impact factor in 2017 was 0.622. It is a multidisciplinary journal, which devotes to road and bridge engineering research. It can be seen that there are small differences among the shown burst durations. The research in TRANSPORT can be related to diverse areas.

Similarly, we complete the burst detection in terms of keywords, which can be seen from Table 8 . The last column of Table 8 shows the citation bursts intensity of keyword from January 2007 to June 2019. The red colour means that the intensity of citation bursts exceeds the set threshold. The red colour means that the intensity of citation bursts exceeds the set threshold. Thus, it can be found that "transport", "terminal", and "automobile" are the earliest burst keywords in 2007. Then, the keywords of "automobile", "network", and "efficiency" have the longest duration for 5 years. In addition, the keywords "design" and "public transport" have received the citation burst recently, which means that these two keywords are still influential for current research. The emerging trends in terms of the research objects and methods change in different time periods. For instance, in the early years, automobile was frequently investigated as a research object from different perspectives. After that, the research objects such as "railway" "biofuel", "ethanol", "Vilnius City", "road", "behaviour", "ship" and "design" have been broadly discussed. Regarding to the research methods in this journal, the 
Table 7. Top 15 cited journals with the strongest citation bursts

\begin{tabular}{|c|c|c|c|c|c|c|}
\hline Rank & Cited journals & Year & Strength & Begin & End & 2007-2019 \\
\hline 1 & Transport and Telecommunication & 2007 & 3.3667 & 2007 & 2010 & 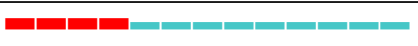 \\
\hline 2 & Transportation Science & 2007 & 3.0974 & 2007 & 2009 & 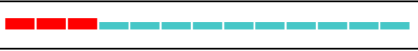 \\
\hline 3 & Journal of Civil Engineering and Management & 2007 & 7.384 & 2008 & 2012 & 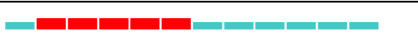 \\
\hline 4 & Informatica & 2007 & 3.3114 & 2008 & 2010 & 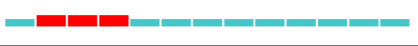 \\
\hline 5 & Atmospheric Environment & 2007 & 2.7557 & 2009 & 2010 & 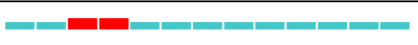 \\
\hline 6 & Journal of Business Economics and Management & 2007 & 3.806 & 2009 & 2013 & 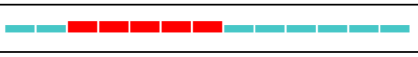 \\
\hline 7 & Modern Physics Letters A & 2007 & 3.2617 & 2009 & 2010 & 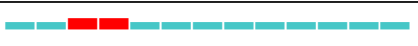 \\
\hline 8 & Energy \& Fuels & 2007 & 3.1516 & 2009 & 2010 & 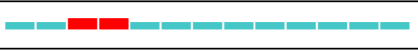 \\
\hline 9 & $\begin{array}{l}\text { Journal of Environmental Engineering and Landscape } \\
\text { Management }\end{array}$ & 2007 & 5.1503 & 2009 & 2012 & \\
\hline 10 & Baltic Journal of Road and Bridge Engineering & 2007 & 3.8197 & 2009 & 2013 & 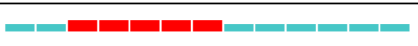 \\
\hline 11 & Technological and Economic Development of Economy & 2007 & 11.3297 & 2009 & 2012 & 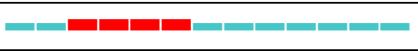 \\
\hline 12 & Solid State Phenomena & 2007 & 4.7393 & 2010 & 2011 & 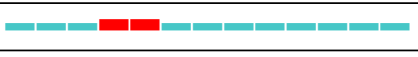 \\
\hline 13 & Inžinerinė Ekonomika - Engineering Economics & 2007 & 5.7325 & 2010 & 2013 & 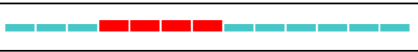 \\
\hline 14 & International Transactions in Operational Research & 2007 & 3.1561 & 2010 & 2011 & 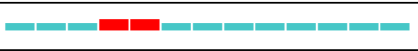 \\
\hline 15 & Applied Mathematics and Computation & 2007 & 6.0593 & 2011 & 2013 & 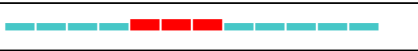 \\
\hline
\end{tabular}

Table 8. Top 20 keywords with the strongest citation bursts

\begin{tabular}{|c|c|c|c|c|c|}
\hline Keyword & Year & Strength & Begin & End & $2007-2019$ \\
\hline Transport & 2007 & 3.4933 & 2007 & 2008 & - \\
\hline Terminal & 2007 & 2.6521 & 2007 & 2009 & 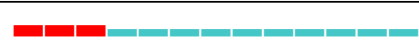 \\
\hline Automobile & 2007 & 2.7169 & 2007 & 2011 & 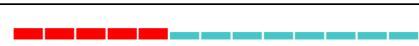 \\
\hline Ranking & 2007 & 3.2058 & 2008 & 2011 & 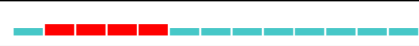 \\
\hline Logistics & 2007 & 2.8149 & 2008 & 2009 & - \\
\hline Railway transport & 2007 & 3.2638 & 2009 & 2010 & (2-1) \\
\hline Biofuel & 2007 & 2.7454 & 2009 & 2012 & 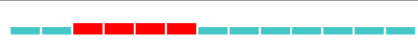 \\
\hline Ethanol & 2007 & 3.2638 & 2009 & 2010 & 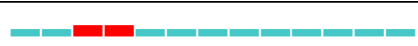 \\
\hline Parameter & 2007 & 3.9427 & 2009 & 2011 & 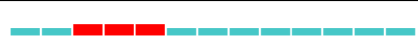 \\
\hline Vilnius City & 2007 & 3.2729 & 2010 & 2011 & 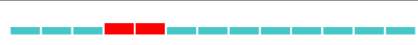 \\
\hline Network & 2007 & 3.5477 & 2011 & 2015 & 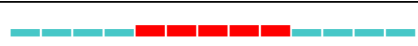 \\
\hline Efficiency & 2007 & 2.6559 & 2011 & 2015 & 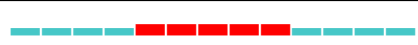 \\
\hline AHP & 2007 & 2.95 & 2012 & 2015 & 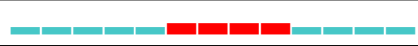 \\
\hline Road & 2007 & 4.7392 & 2013 & 2016 & (2-2) \\
\hline Behaviour & 2007 & 3.6612 & 2014 & 2016 & 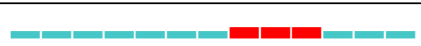 \\
\hline Ship & 2007 & 3.1286 & 2014 & 2016 & 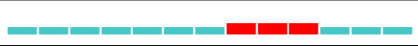 \\
\hline Mode choice & 2007 & 2.8476 & 2014 & 2015 & 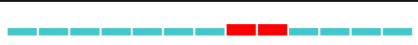 \\
\hline System & 2007 & 4.4169 & 2015 & 2017 & 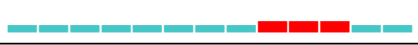 \\
\hline Design & 2007 & 3.5895 & 2016 & 2019 & 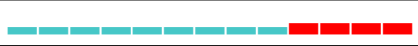 \\
\hline Public transport & 2007 & 2.7828 & 2017 & 2019 & 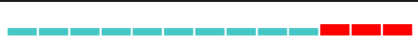 \\
\hline
\end{tabular}

papers that focus on "ranking", "parameter", "AHP” and "mode choice" have gained more attention.

Keywords analysis is a useful tool to derive the hot topics in a research field. Figure 7 is a visualized keyword network of TRANSPORT publications. It is found that the keywords of "model" and "system" occur the most with 95 and 79 times, respectively. Then, the authors pay more attention to modelling and developing system in this journal. To further show the keywords of this journal, we also list the cluster network of keywords of TRANSPORT in Figure 8. These keywords are divided into 7 clusters by category. The largest cluster is "operational parameter", which includes 58 keywords, suggesting that most of authors focus on operational parameter. The following cluster is "strong influence" and the third largest cluster is "urban area". Therefore, the influences related to transport issues and the relative urban constructions are also the crucial research directions of this journal. 


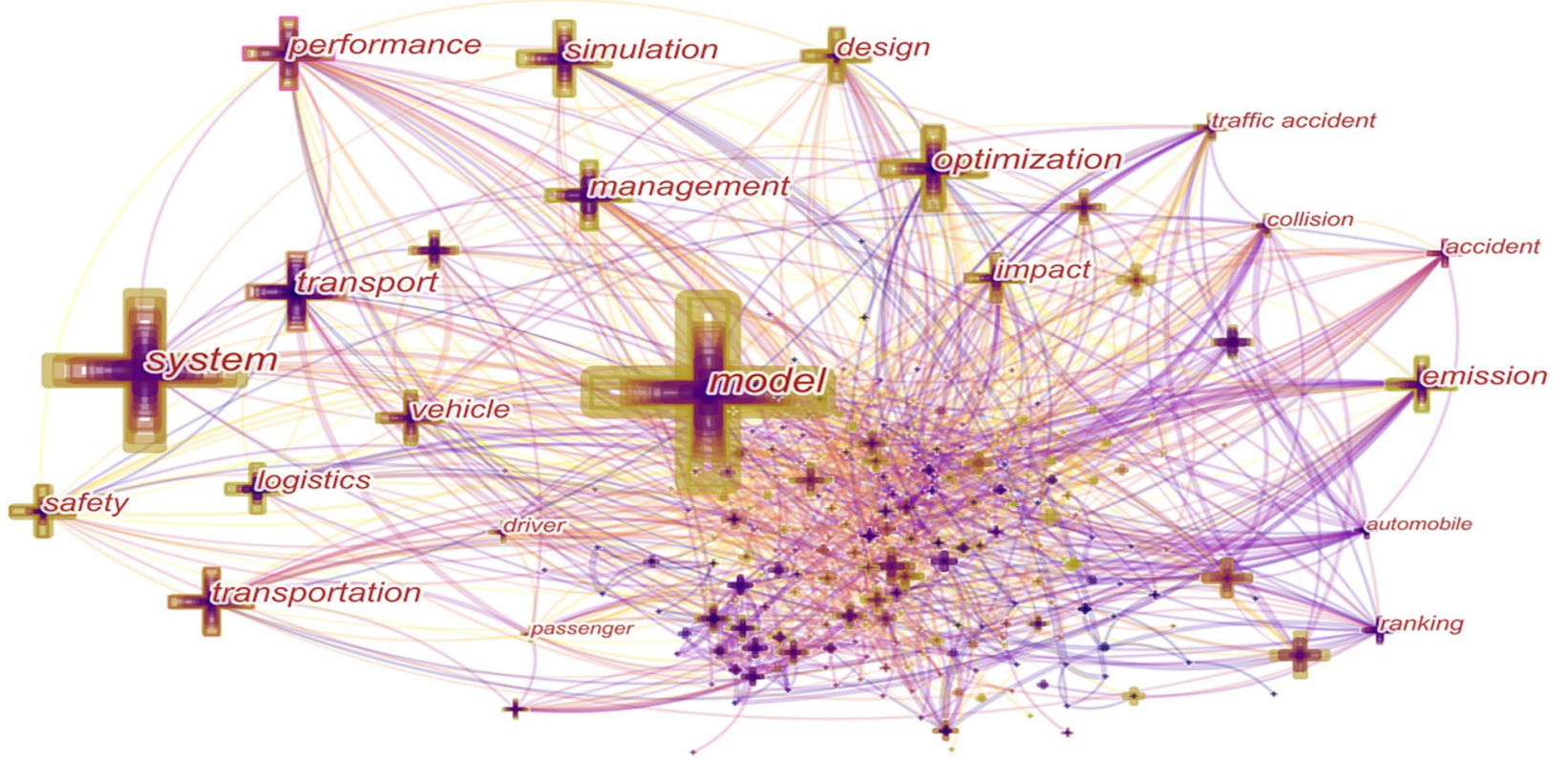

Figure 7. A visualization of the keywords network

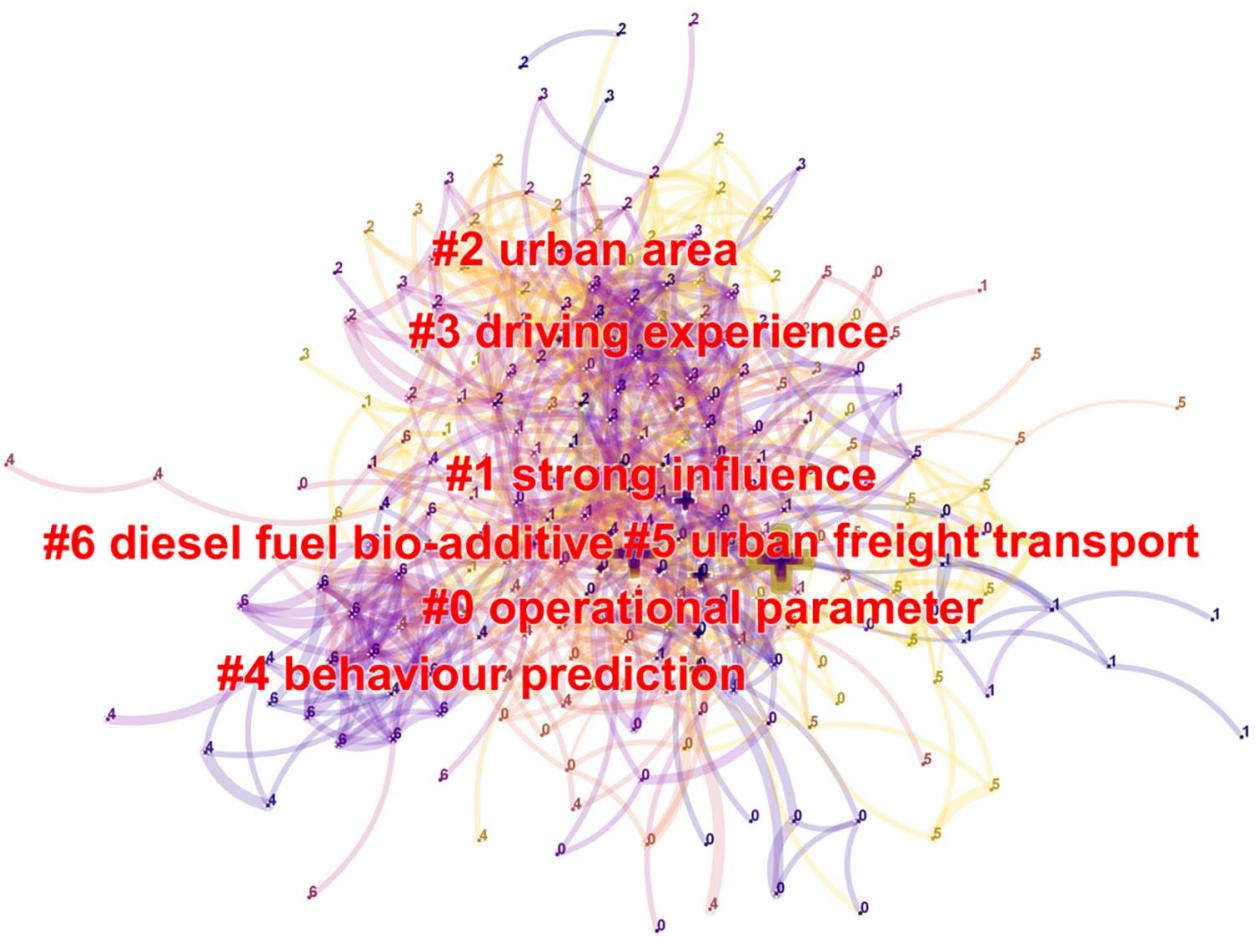

Figure 8. Cluster network of keyword research of TRANSPORT

Lastly, Figure 9 is given to show the timeline view of the keywords. It clearly illustrates the hot topics of this journal's research in different periods. At the initial phase, from 2007 to 2010, the authors of this journal focused on the keywords "urban transportation", "terminal", "train", "braking parameter", "supply chain management logistics", "vehicle", and "TOPSIS method". Then, from 2010 to 2013, the keywords "genetic algorithm", "road pavement", "road safety", "road tank", "road accident", and "service" occurred the most, which reflects that the authors cared more about traffic safety in this period. From 2013 to 2016, the key- words "heterogeneous traffic", "optimization method", "information system", "intelligent transport system", "stability", and "operating speed" were studied, indicating that the authors devoted to developing the transport system. From 2016 to 2019, the authors focused on "automation", "injury severity", "neural network", "bus rapid transit", "perceived value", "customer satisfaction", and "numerical simulation", which means they pay attention to transport service. Compared with the keywords in these periods, it can be found that with the development of transport, the hot topics continually change over time. 


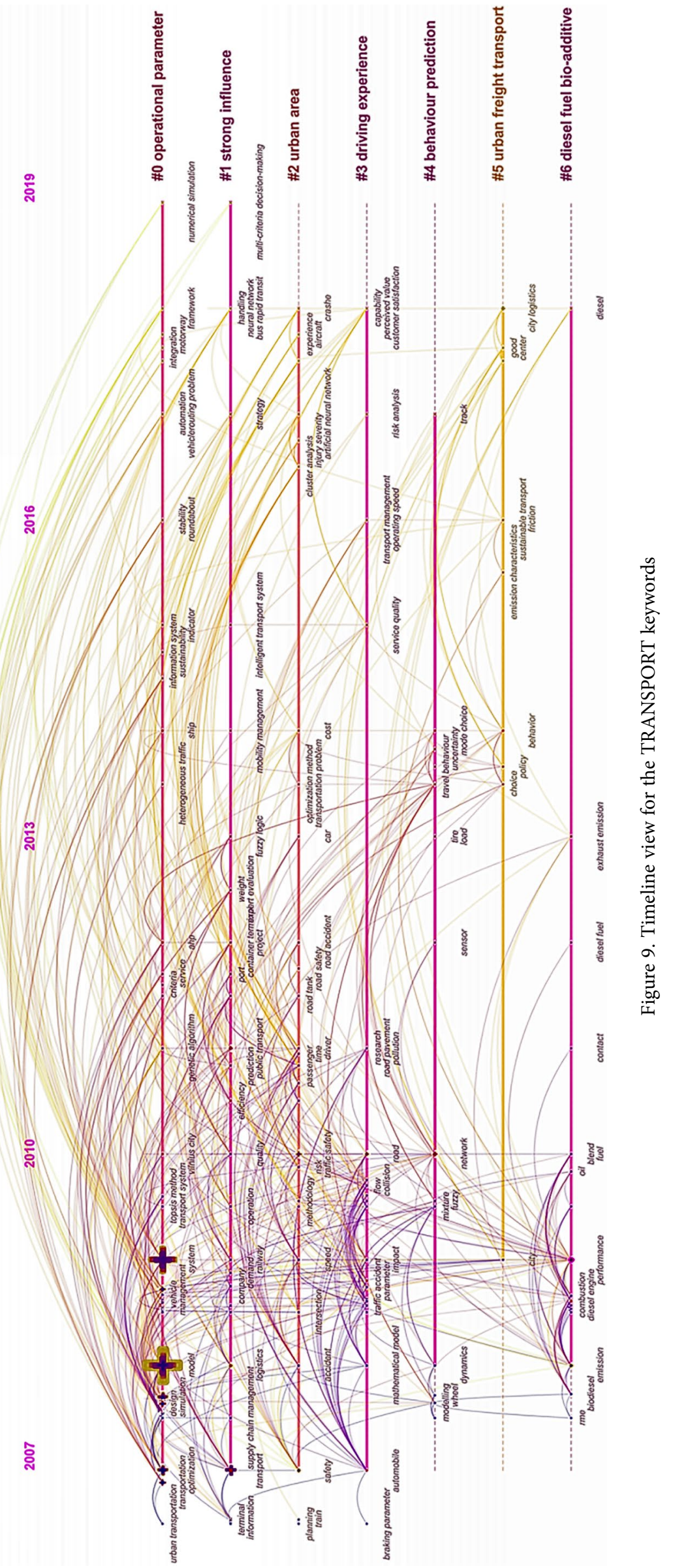




\section{Conclusions}

This paper has provided a comprehensive bibliometric overview and visualizes the research domain of the famous journal TRANSPORT. To do so, two bibliometric tools have been used to analyse the data retrieved from Clarivate Analytics Web of Science. In this paper, we have firstly summarized the editor team, the history publications, the citation numbers and citation structure of all the publications, the influential contributors on the aspects of papers, countries, institutions and authors, the burst detection analyses of cited journals, and the keywords and keyword analysis of TRANSPORT based on its 704 papers from January 2007 to June 2019. It can be found that many papers were published in 2018 with a large number of citations. The paper "Multi-objective decision-making for road design" (Brauers et al. 2008) is the most influential paper. As for the top 20 keywords with the strongest citation bursts, the keywords "automobile", "network" and "efficiency" receive the longest burst durations. In 2007, the emerging trends of the research outputs in this journal can be related to automobile, which is a commonly used transport way in people's daily life. In recent years, the emerging trends of this journal tend to be "design" and "public transport", indicating that technological innovations and public awareness have also attracted researchers' attention. In terms of the keywords analysis, "model" and "system" have occurred the most. In the keyword cluster network, we have found that "operational parameter" is the biggest cluster. Finally, from the timeline view analysis. It can be seen that the hot topics of this journal continually change over time and the authors pay more attention to transport service recently.

Through the above analyses, the current status and the emerging trends of the research published on TRANSPORT can be comprehensively learned, which helps researchers know more about this journal and transport-related investigations directly. Further research that involves diverse angles of an area's knowledge domain should be provided to present more deep insights.

\section{Acknowledgements}

This work was supported by the Natural Science Foundation of China (No 71561026, No 71571123 and No 71840001).

\section{Author contributions}

Prof. Wei Zhou and Prof. Zeshui Xu are the main authors, which are responsible for the preparation of the manuscript.

Managing Editor of the research journal TRANSPORT MSc. Paulius Skačkauskas is responsible for the editing and the revisions of the manuscript.

\section{Disclosure statement}

Authors do not have any competing financial, professional, or personal interests from other parties.

\section{References}

Audi, R. 2015. The Cambridge Dictionary of Philosophy. Cambridge University Press. $1161 \mathrm{p}$. https://doi.org/10.1017/CBO9781139057509

Brauers, W. K. M.; Zavadskas, E. K.; Peldschus, F.; Turskis, Z. 2008. Multi-objective decision-making for road design, Transport 23(3): 183-193.

https://doi.org/10.3846/1648-4142.2008.23.183-193

Chen, C. 2004. Searching for intellectual turning points: progressive knowledge domain visualization, Proceedings of the $\mathrm{Na}$ tional Academy of Sciences of the United States of America 101: 5303-5310. https://doi.org/10.1073/pnas.0307513100

Chen, C.; Hu, Z.; Liu, S.; Tseng, H. 2012. Emerging trends in regenerative medicine: a scientometric analysis in CiteSpace, Expert Opinion on Biological Therapy 12(5): 593-608. https://doi.org/10.1517/14712598.2012.674507

Cui, T.; Zhang, J. 2018. Bibliometric and review of the research on circular economy through the evolution of Chinese public policy, Scientometrics 116(2): 1013-1037.

https://doi.org/10.1007/s11192-018-2782-y

Díaz, I.; Cortey, M.; Olvera, À.; Segalés, J. 2016. Use of $h$-index and other bibliometric indicators to evaluate research productivity outcome on swine diseases, Plos One 11(3): e0149690. https://doi.org/10.1371/journal.pone.0149690

Ekanayake, E.; Shen, G.; Kumaraswamy, M. 2019. Mapping the knowledge domains of value management: a bibliometric approach, Engineering, Construction and Architectural Management 26(3): 499-514.

https://doi.org/10.1108/ECAM-06-2018-0252

Heersmink, R.; Van Den Hoven, J.; Van Eck, N. J.; Van den Berg, J. 2011. Bibliometric mapping of computer and information ethics, Ethics and Information Technology 13(3): 241-249. https://doi.org/10.1007/s10676-011-9273-7

Kleinberg, J. 2002. Bursty and hierarchical structure in streams, in KDD'02: Proceedings of the Eighth ACM SIGKDD International Conference on Knowledge Discovery and Data Mining, 23-26 July 2002, Edmonton, Alberta, Canada, 91-101. https://doi.org/10.1145/775060.775061

Kozak, M.; Bornmann, L.; Leydesdorff, L. 2015. How have the Eastern European countries of the former Warsaw Pact developed since 1990? A bibliometric study, Scientometrics 102(2): 1101-1117. https://doi.org/10.1007/s11192-014-1439-8

Morar, M.; Agachi, P. S. 2010. Review: important contributions in development and improvement of the heat integration techniques, Computers \& Chemical Engineering 34(8): 11711179. https://doi.org/10.1016/j.compchemeng.2010.02.038

Niazi, M.; Hussain, A. 2011. Agent-based computing from multiagent systems to agent-based models: a visual survey, Scientometrics 89(2): 479-499.

https://doi.org/10.1007/s11192-011-0468-9

Qaiser, F.; Ahmed, K.; Sykora, M.; Choudhary, A.; Simpson, M. 2017. Decision support systems for sustainable logistics: a review and bibliometric analysis, Industrial Management \& Data Systems 117(7): 1376-1388.

https://doi.org/10.1108/IMDS-09-2016-0410

Reyes-Gonzalez, L.; Gonzalez-Brambila, C. N.; Veloso, F. 2016. Using co-authorship and citation analysis to identify research groups: a new way to assess performance, Scientometrics 108(3): 1171-1191.

https://doi.org/10.1007/s11192-016-2029-8

Sivilevičius, H. 2011. Modelling the interaction of transport system elements, Transport 26(1): 20-34.

https://doi.org/10.3846/16484142.2011.560366 
Small, H. 1973. Co-citation in the scientific literature: a new measure of the relationship between two documents, Journal of the American Society for Information Science 24(4): 265269. https://doi.org/10.1002/asi.4630240406

Stopar, K.; Bartol, T. 2019. Digital competences, computer skills and information literacy in secondary education: mapping and visualization of trends and concepts, Scientometrics 118(2): 479-498. https://doi.org/10.1007/s11192-018-2990-5

Sweileh, W. M. 2017. Global research trends of World Health Organization's top eight emerging pathogens, Globalization and Health 13: 9. https://doi.org/10.1186/s12992-017-0233-9

Turskis, Z.; Zavadskas, E. K. 2010. A new fuzzy additive ratio assessment method (ARAS-F). Case study: the analysis of fuzzy multiple criteria in order to select the logistic centers location, Transport 25(4): 423-432.

https://doi.org/10.3846/transport.2010.52

Van Eck, N. J.; Waltman, L. 2007. VOS: a new method for visualizing similarities between objects, in R. Decker, H. J. Lenz (Eds). Advances in Data Analysis. Studies in Classification, Data Analysis, and Knowledge Organization, 299-306. https://doi.org/10.1007/978-3-540-70981-7_34

Yeung, A. W. K.; Goto, T. K.; Leung, W. K. 2017. The changing landscape of neuroscience research, 2006-2015: a bibliometric study, Frontiers in Neuroscience 11: 120. https://doi.org/10.3389/fnins.2017.00120

Yu, D.; Xu, Z.; Fujita, H. 2019a. Bibliometric analysis on the evolution of applied intelligence, Applied Intelligence 49(2): 449-462. https://doi.org/10.1007/s10489-018-1278-Z

Yu, D.; Xu, Z.; Šaparauskas, J. 2019b. The evolution of "Technological and economic development of economy": a bibliometric analysis, Technological and Economic Development of Economy 25(3): 369-385. https://doi.org/10.3846/tede.2019.10193

Yu, D.; Xu, Z.; Wang, W. 2019c. A bibliometric analysis of fuzzy optimization and decision making (2002-2017), Fuzzy Optimization and Decision Making 18(3): 371-397. https://doi.org/10.1007/s10700-018-9301-8

Yu, D.; Xu, Z.; Wang, X. 2019d. Bibliometric analysis of support vector machines research trend: a case study in China, International Journal of Machine Learning and Cybernetics, 1-14. https://doi.org/10.1007/s13042-019-01028-y

Zhang, X.; Gao, Y.; Yan, X.; Ordóñez de Pablos, P.; Sun, Y.; Cao, X. 2015. From $e$-learning to social-learning: mapping development of studies on social media-supported knowledge management, Computers in Human Behavior 51: 803-811. https://doi.org/10.1016/j.chb.2014.11.084

Zhao, F.; Shi, B.; Liu, R.; Zhou, W.; Shi, D.; Zhang, J. 2018. Theme trends and knowledge structure on choroidal neovascularization: a quantitative and co-word analysis, BMC Ophthalmology 18: 86. https://doi.org/10.1186/s12886-018-0752-Z 